\title{
Numerical analysis of a heat exchanger pile response in a Brazilian subtropical region
}

\author{
Roberto Pimentel de Sousa Júnior ${ }^{1,{ }^{*}}$, and Renato Pinto da Cunha ${ }^{1}$ \\ ${ }^{1}$ UnB, University of Brasília, Brasília, Brazil
}

\begin{abstract}
Ground-coupled heat exchanger systems have been used as acclimatization systems for residential and commercial buildings in many countries. Brazil is the ninth largest consumer of electrical energy in the world, for this reason, local researchers are investigating the use of the energy piles in order to reduce the consumption of electricity. Thermal response tests have been carried out on a heat exchanger pile at the geotechnical experimental site of the University of São Paulo in São Carlos city, a region of subtropical climate. Simultaneously, using the thermal properties obtained in these tests, numerical analysis has been performed to investigate the heat exchange performance of energy piles installed in this site. For this numerical analysis, the effect of soil and concrete properties, pile geometry and the flow rate on the pile thermal response were evaluated. The current paper presents the results obtained by the analysis of 67 models tested to found an optimal configuration of an energy pile through the software COMSOL, using Heat Transfer and Non-Isothermal Pipe Flow modules. From this work, it was observed that the optimal configuration was obtained for a turbulent flow condition in piles in the heat exchanger pipes.
\end{abstract}

\section{Introduction}

In the last 40 years the world has constantly worked in topics related to the environmental sustainability of countries. Forced solutions due to the dynamic of resources such as oil market have been important to improve the energy matter. In response of this dynamic, especially after the oil crisis, some technologies were developed to provide answers and in this manner were implemented soil heat exchangers systems as a solution for residential and commercial energy utilization.

However, the Latin America region has not solved its dependence on oil for energy. Brazil is not far from this reality, since the country has an energy supply based on a $42.6 \%$ oil and $37.6 \%$ renewable resources. The importance of sustainable energy sources is increasing, so energy piles are a good solution to help address this. Therefore, in this paper the heat transfer performance of different configurations of energy piles in a site were evaluated using numerical simulations. COMSOL Multiphysics was used to analyse the efficiency of the pile varying loop and geometrical configurations as the flow rate, pipe configuration, length and diameter of the energy pile system according to a Thermal Response Test (TRT) performed at Sao Carlos-SP in Brazil.

\section{Background}

Five Thermal Response Tests were carried out in the field experimental area of the University of Sao Paulo in Sao Carlos's city (EESC). The heat exchanger pile TRT-
1 with heat exchange rate, by the study who authors did, result $77.92 \mathrm{~W} / \mathrm{m}$ [7] is taken to make a numerical study.

The surrounding soil of the test consists of five strata: the shallow layer is a coarse and fine clayey sand sediment of $6.40 \mathrm{~m}$ thick, a rubble line about $0.50 \mathrm{~m}$ thick, a layer corresponding to a residual deposit composed by a fine clayey sand about $6.1 \mathrm{~m}$ thick, followed by a sandstone saprolite (Itaqueri formation) composed by a clayey sand of $11 \mathrm{~m}$ thick, and finally, a basalt saprolite of a silty clay (Serra Geral formation) which repose in a weathered sandstone bedrock (Botucatu formation).

\section{Mathematical formulation}

Simulations in COMSOL Multiphysics were applied thermal and hydraulic equations that govern the energy transfer problem in a heat exchanger pile. The thermal flux passes over liquids and solids materials: the fluid flow, pipes, concrete and soil. Hence, the heat transfer related to heat exchanger piles combines conduction and convection processes to have energy transfer between the ground and the fluid. The equations used for the simulations and described in [8] considering thermal conductivity, specific heat capacity, mass and momentum conservation, heat balance equation in a 1D pipe, Darcy's friction factor and Reynolds number.

\footnotetext{
* Corresponding author: eng.robertopimentel@gmail.com
} 


\section{Model description}

Models consist in a 1D and 3D analysis which is simulated a thermal response test of 48 hours, time chosen by the authors. The soil domain dimensions are about 3 meter of radius and height of $17 \mathrm{~m}$ and a concrete pile into the soil domain. The Heat Exchanger piles are vertical concrete boreholes with different Upipes configurations embedded along the shaft of the piles. The pile diameter takes values from 0.25 to 1.05 meters and pile length from 6 to 30 meters. In this study was chosen the pile with $30 \mathrm{~cm}$ diameter. A hydraulic analysis was considered with single, double and triple Upipes as well as also the fluid flow rate into the pipe(s). The pipe diameter is $2.54 \mathrm{~cm}$ ( 1 in) and a thickness rage from $2 \mathrm{~mm}$ to $10 \mathrm{~mm}$. The concrete cover for all pipes is $0.05 \mathrm{~m}$. They were carried out 67 simulations to determine the optimal system configuration that achieve the best thermal performance. The parametric study of the heat exchanger pile consists of varying geometry, thermal properties and hydraulic configurations of the system. Additionally, an analysis of the soil thermal conductivity influence is carried out as complement. The hydraulic analysis aims to evaluate the heat exchange efficiency of the piles in the laminar, transitional and turbulent regime.

Material properties used for simulations are shown in Table (I). Soil material properties were set up according to Castillo, H. (2016) [8] and the thermal conductivity of soil(ks) were taken according to Neto (2015) [7].

Meaning of material properties showed below:

$\mathrm{Cp}$ : heat capacity

ks: thermal conductivity of soil forming minerals

$\rho$ : apparent density of soil

e: void ratio (dimensionless number)

Table 1. Material properties (*Saturated condition).

\begin{tabular}{|c|c|c|c|c|}
\hline Material & $\begin{array}{c}\mathrm{Cp} \\
\mathrm{J} / \mathrm{kgK}\end{array}$ & $\begin{array}{c}\mathrm{ks} \\
\mathrm{W} / \mathrm{mK}\end{array}$ & $\begin{array}{c}\rho \\
\mathrm{kg} / \mathrm{m}^{3}\end{array}$ & $\mathrm{e}$ \\
\hline Sediments & 1208 & 2.42 & 1573 & 0.96 \\
\hline Rubble & 1267 & 2.42 & 1810 & 0.78 \\
\hline $\begin{array}{c}\text { Fine } \\
\text { clayey } \\
\text { sand }\end{array}$ & 1250 & 2.42 & 1960 & 0.63 \\
\hline $\begin{array}{c}\text { Fine } \\
\text { clayey } \\
\text { sand* }\end{array}$ & 1369 & 2.42 & 2043 & 0.63 \\
\hline $\begin{array}{c}\text { Clayey } \\
\text { sand* }\end{array}$ & 1468 & 2.42 & 1984 & 0.78 \\
\hline $\begin{array}{c}\text { Concrete } \\
\text { HDPE }\end{array}$ & - & 0.48 & - & - \\
\hline \multicolumn{2}{|c|}{1000} & 2.00 & 2400 & - \\
\hline
\end{tabular}

About the ks (thermal conductivity of soil forming minerals), the value was the same for different soil layers because this propriety was calculated using the results of the TRT. Them this value 2,42 is an average for the soil in contact with the pile, no matter if the soil is in saturated conditions or not.

\subsection{Initial conditions}

Initial conditions were applied to models according to measurements performed in the experimental field during thermal response tests [7]. These conditions were imposed on models to obtain an approximation in the thermal flux results. At time zero the heat exchanger pile model has the following initial conditions (shown in Fig.1):

- Soil temperature at the surface is the atmospheric temperature $23.8^{\circ} \mathrm{C}(296.95 \mathrm{~K})$.

- Temperature at $3.50,7.50$ and 11.5 meters were registered as $24^{\circ} \mathrm{C}(297.15 \mathrm{~K}), 24.1^{\circ} \mathrm{C}(297.25 \mathrm{~K})$ and $24.2^{\circ} \mathrm{C}(297.35 \mathrm{~K})$ respectively. Transitions between these records were assumed as linear temperature variation.

- $\quad$ Pipes, water and pile with same the soil temperature.

- Water velocity is $0.01 \mathrm{~m} / \mathrm{s}$.

- Outlet pressure is $102100 \mathrm{~Pa}$.

\subsection{Boundary conditions}

Some thermal boundary conditions in domains as well as 1D and 3D domains were imposed in models: a Thermal isolation around the soil domain in order to not allow external thermal interactions with the soil. A constant thermal condition with $24^{\circ} \mathrm{C}(297.15 \mathrm{~K})$ below the soil domain simulate the depth constant temperature along the year. Furthermore, a thin layer of isolating air is used as a buffer between the soil/pile and the boundary condition. This buffer is about $10 \mathrm{~mm}$ of thickness, enough to simulates the heat transfer from the the atmosphere to the domain surfaces.

The inlet temperature shown in Fig.1 and fluid flow rate behavior in Fig. 2 were imposed in the TRT model. And finally, the soil's temperature at the surface varies according Fig. 4 monitored during the test.

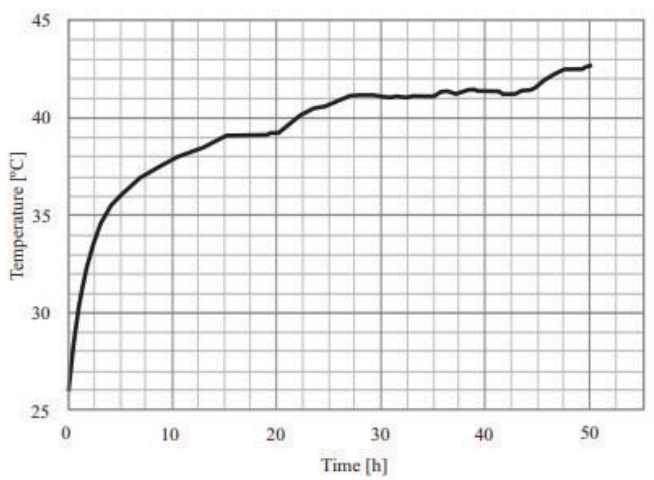

Fig. 1. Inlet fluid temperature (Neto, 2015).

\subsection{Sensitivity study and validation of the numerical model}

A sensitivity study for finite elements was carried out to obtain a certain time of process, guarantee precision and proximity in results. Sensitivity analysis for soil domain geometry form (Cylindrical or hexahedral geometry) and the element size of the finite elements were considered 
on this subject. Furthermore, a progressive density of the mesh was evaluated. Finally, a validation process was carried out between the experimental and numerical model to check the result proximity.

Sensitivity results suggest a cylindrical form and tetrahedral finite elements for the soil domain to ensure a less process time for results. Pipe elements simulated as 1D were configured in order to generate a fine mesh density and not distort thermal results between nodes. With these guidelines time can be save in a $72 \%$ with a maximum acceptable error of $5.6 \%$ in the final thermal flux and $0.2 \%$ in outlet temperature [8].

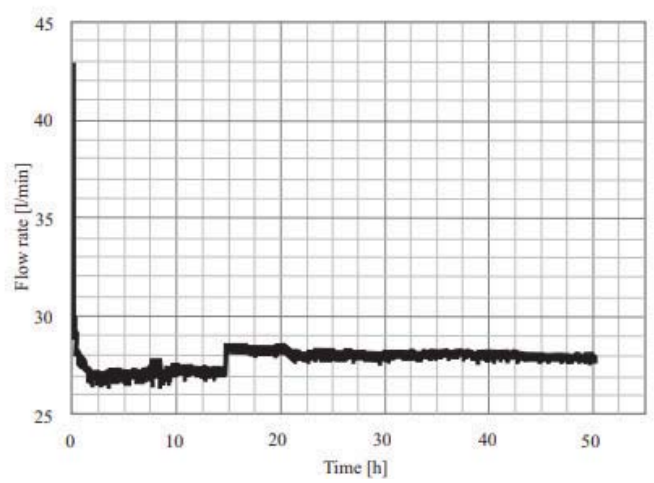

Fig. 2. Entrance flow rate.

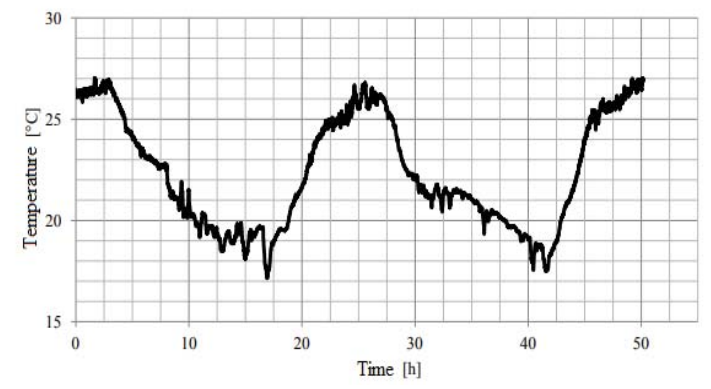

Fig. 3. Temperature on the soil surface.

\section{Results and discussions}

\subsection{Model Validation}

Numerical results achieved through COMSOL Multiphysics determine the evolution of temperature at the outlet side of the heat exchanger pile. The evolution of temperature in numerical and experimental results for 48 hours is shown in Fig.4. The numerical result shows that the fluid temperature at the output responds initially with temperatures near the soil temperature $\left(23.8^{\circ} \mathrm{C}\right)$. Then the temperature was increased to an almost constant value close to $41^{\circ} \mathrm{C}$ approximately. This thermal behaviour was observed after approximately 27 hours (97200 s).

\subsection{Thermal Performance analysis}

A thermal performance analysis was carried out in order to establish the optimal configuration for the thermal system. A parametric study was performed varying pile length and diameter, number of pipes and flow rate, soil and concrete thermal conductivity, the average inlet temperature and the pipe thickness. So, for the evaluation of the effect pile diameter on the heat exchange rate was used a single U-loop for the pile with greater diameters. This analysis helps understand how sensitive the thermal performance is with each studied parameters and provides an optimal configuration to obtain a higher heat exchanger rate for the pile system studied in Sao Carlos, Brazil.

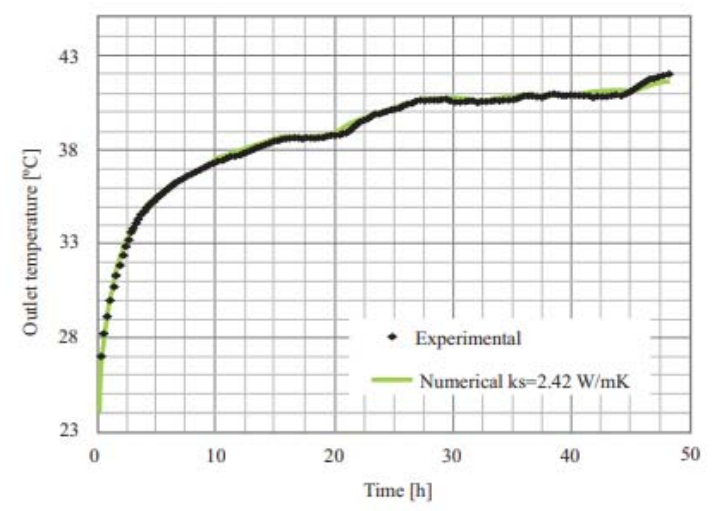

Fig. 4. Experimental vs. numerical results.

Pile Length: The pile length was varied according to the geology. Is considered $30 \mathrm{~m}$ depth as the acceptable bearing capacity according to the bearing capacity results obtained in Sao Carlos University [9]. For simulations were considered pile lengths of $6,12,15,18$, 21, 24, 27 and 30 meters. The thermal performance results with the pile length variation are shown in Figs. (6) and (7). In this case as pile length is increasing the total heat exchanger rate increase proportionally from $446 \mathrm{~W}$ to $2080 \mathrm{~W}$. In the other hand, the normalized heat exchanger rate has a general tendency to decrease from 74.3 W/m (for $6 \mathrm{~m}$ ) to $69.3 \mathrm{~W} / \mathrm{m}$ (for $30 \mathrm{~m}$ ) corresponding to a heat flux variation of $7 \%$ of the minimum heat flux result.

Pile Diameter: The Pile diameter was varied from 0.25 to 1.05 meters using only 1U-loop for the study. Fig.7 shows the heat exchange rate response and indicates that the pile thermal performance is improved as it takes a greater value of diameter. The heat exchange rate increase from $73.5 \mathrm{~W} / \mathrm{m}$ to $89.7 \mathrm{~W} / \mathrm{m}$ that corresponds to a $16.2 \mathrm{~W} / \mathrm{m}$ of difference. This parameter produces an important utilization range and an important variation of $22 \%$ of the thermal flux. The pile thermal performance is not completely linear with the pile diameter, but it points to have a higher thermal response when it takes the value of $0.85 \mathrm{~m}$. As a general observation, the heat exchanger pile takes advantage of the pile geometry to improve the total heat exchange rate when the volume of the pile increases.

Number of pipes and Flow Rate: Hydraulic parameters are very important according to Cecinato and Loveridge [10] and Bidarmaghz et al. (2013) [1]. Number of U-single pipes (with hydraulic diameter of 
$2.54 \mathrm{~cm}$ ) and the flow rate were evaluated in order to analyse the thermal performance due to variation of these parameters. Models with 1, 2 and 3 single U pipes with flow rate values of $1.18,2.47,3.53,5.89,9.42$, 17.70 and 27.78 liters per minutes $[1 / \mathrm{min}]$ were simulated. Fig. 8 shows the general information about each pile system configuration with single U-pipe, double U-pipe and triple U-pipe.

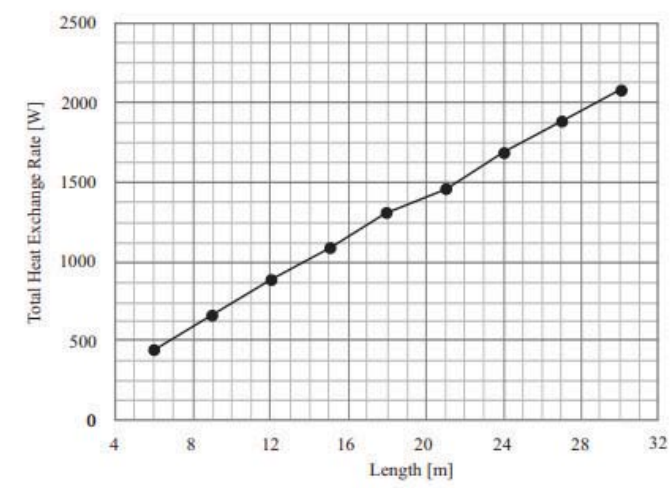

Fig. 5. Total heat exchange rate and variation of pile length.

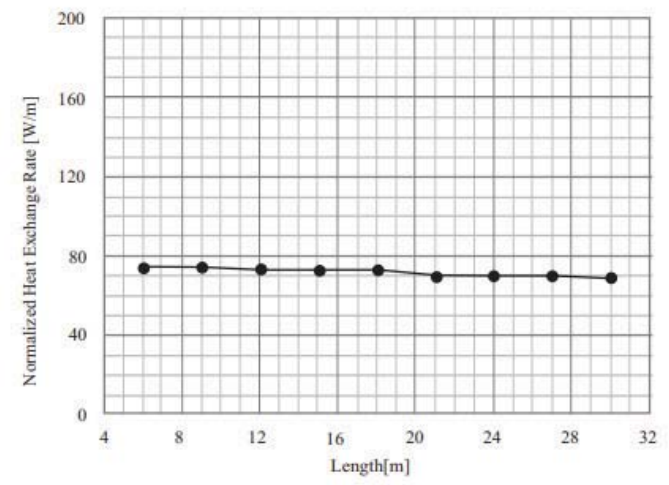

Fig. 6. Normalized heat exchange rate and variation of pile length.

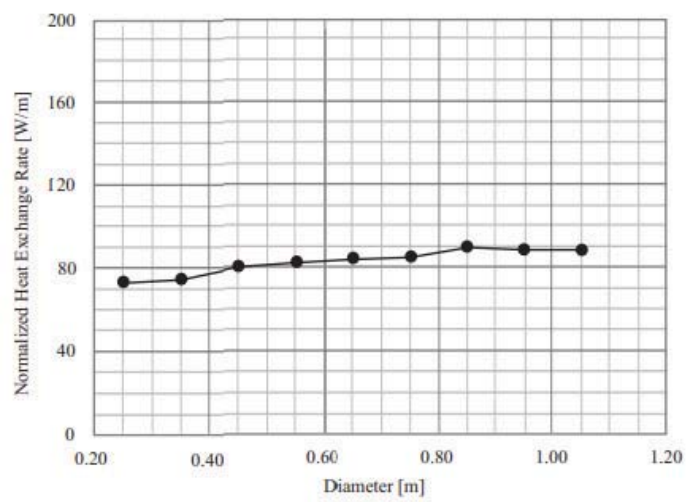

Fig. 7. Normalized heat exchange rate and variation of pile diameter.

Fig. 9 shows the heat exchange rates archived with 6 different flow rate values for each case of U-pipe configuration. It is noted that the thermal performance is improving while the number of pipes is increasing. For a simple U-pipe configuration it seems that about $9.0 \mathrm{l} / \mathrm{min}$ (turbulent regime) the heat exchange rate start to be constant when the flow rate increase their value. For double (parallel) and triple U-pipe exist little gap (an average of $12 \%$ ) between the thermal response for each flow rate. Before $18 \mathrm{l} / \mathrm{min}$ double and triple U-pipes configurations increase the growth rates of the heat flux and gain more heat exchange capacity with the surrounding soil. Between single and triple U-pipe configurations the variation in heat exchange rates is about $74 \%$.

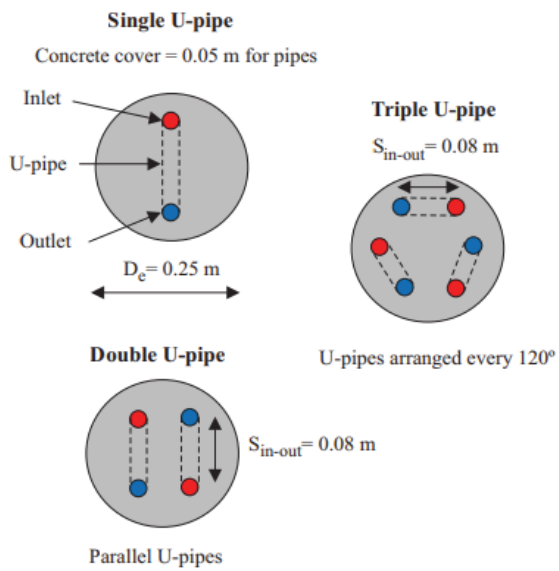

Fig. 8. U-pipes configurations used for simulations (250 $\mathrm{mm}$ diameter).

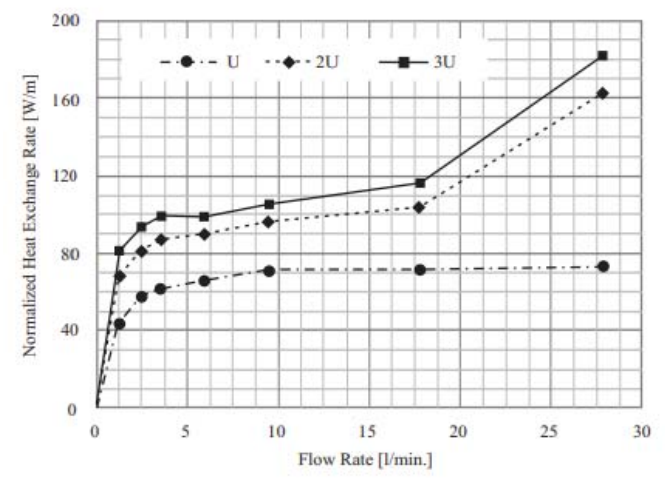

Fig. 9. Normalized heat exchange rate and variation of flow rate and number for a pile with diameter of $25 \mathrm{~cm}$ and length of $12 \mathrm{~m}$.

Soil thermal conduction: For the single U-pipe configuration the heat exchange rate increase from $43.8 \mathrm{~W} / \mathrm{m}$ to $73.5 \mathrm{~W} / \mathrm{m}$ that means a difference of 29.8 $\mathrm{W} / \mathrm{m} .68 \%$ that represents a heat flux variation of $68 \%$. Meanwhile the double U-pipe configuration achieved heat exchange rates from $68.1 \mathrm{~W} / \mathrm{m}$ to $163.7 \mathrm{~W} / \mathrm{m}$ that means a difference of $95.6 \mathrm{~W} / \mathrm{m}$ and corresponds to a thermal flux variation of $140 \%$. Finally, for a triple Upipe configuration the thermal response increases from $81.2 \mathrm{~W} / \mathrm{m}$ to $183.0 \mathrm{~W} / \mathrm{m}$ with a heat exchange rate difference about $102 \mathrm{~W} / \mathrm{m}$ that means a heat flux variation about $126 \%$. 4) Soil thermal conductivity: The soil thermal conductivity was varied between $-20 \%$ and $+20 \%$ of the standard heat exchange rate obtained in the 
thermal response test (TRT). Variations simulate soil thermal and physic properties changes. The $20 \%$ is a representable value for this study (values above or below this value were not considering). Fig. 10 shows results for heat exchange rate with the thermal parameter. It is observed that performance of the heat exchanger pile improved when the soil thermal conductivity increase. The heat exchange rate performance increase from $69.6 \mathrm{~W} / \mathrm{m}$ to $79.6 \mathrm{~W} / \mathrm{m}$, it means a gap of $7.5 \mathrm{~W} / \mathrm{m}$ that represents a $10 \%$ of the least heat exchange rate obtained. It is notice that the thermal performance tendency is linear with this parameter and heat exchange rate can vary about $1.75 \mathrm{~W} / \mathrm{m}$ every $5 \%$ of the soil thermal conductivity variation.

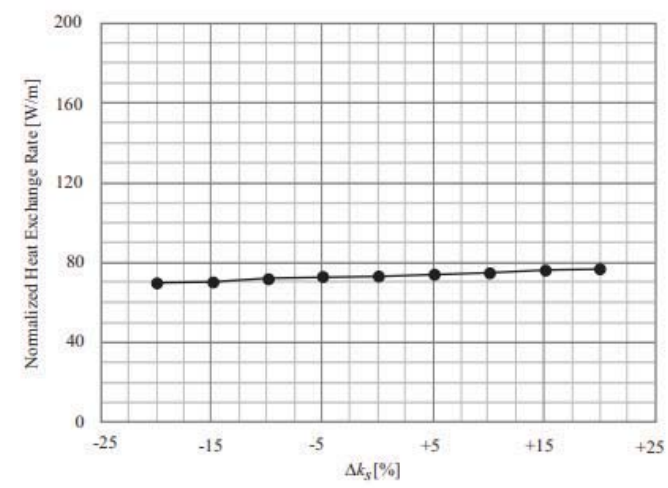

Fig. 10. Normalized heat exchange rate and variation of $\mathrm{ks}$ for a pile with $25 \mathrm{~cm}$ diameter and $12 \mathrm{~m}$ depth.

Concrete thermal conductivity due to the composition: Concrete thermal conductivity (kc) was varied from $1.25 \mathrm{~W} / \mathrm{mK}$ to $3.00 \mathrm{~W} / \mathrm{mK}$ in order to simulate the concrete change in the real model. Thermal conductivity values were simulated according to the ISO values [2] for concrete types (with/without steel, additions, etc.). Variations of the thermal properties concrete depend on the concrete aggregate and minerals [4] that compose the mixture. Results shown in Fig. 11 indicates that heat exchange rate increase while the thermal conductivity increase too but with a non-linear behaviour. Values goes from $56.4 \mathrm{~W} / \mathrm{m}$ to $85.6 \mathrm{~W} / \mathrm{m}$ with a gap of $29.2 \mathrm{~W} / \mathrm{m}$ and means about $52 \%$ of variation of the least heat flux result. This variation is considered when concrete properties as density is altered, while local variations can be considered due to temperature change in concrete (this variation in heat exchange rate will be lower than variations due to the concrete type variation).

Pipe thickness: The HDPE pipe thickness was varied to evaluate the influence between the pipe thermal resistivity and the thermal performance of the pile system. This parameter varies from 2 to 10 millimeters (mm) according to the market of standardized pipes for this application. Fig. 12 shows 7 the thermal results of heat exchange rate influenced of this parameter. It is observed that the heat flux is reduced while the pipe thickness is increasing its value. This result means that the increase of the pipe thermal resistivity influence negatively in the pipe performance. The heat exchange rate is reduced from $77.6 \mathrm{~W} / \mathrm{m}$ to $55.3 \mathrm{~W} / \mathrm{m}$ with a gap of $22.3 \mathrm{~W} / \mathrm{m}$ that corresponds about $28.7 \%$ of variation of the minimum heat pile exchanger performance.

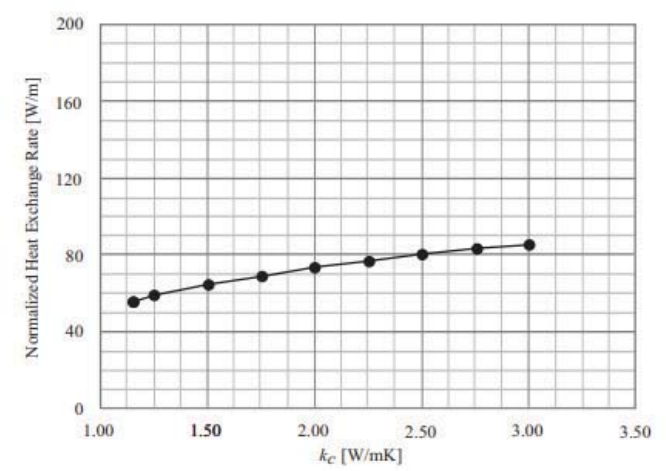

Fig. 11. Normalized heat exchange rate and variation of kc (concrete type).

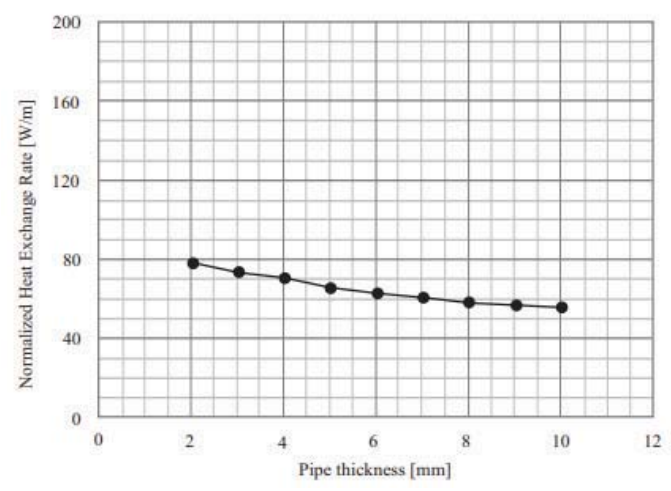

Fig. 12. Normalized heat exchange rate and variation of pipe thickness.

Average inlet temperature: The average inlet temperature for the standard TRT model was $39.4^{\circ} \mathrm{C}$ $(312.55 \mathrm{~K})$. Models with inlet temperature variations were simulated from $30^{\circ} \mathrm{C}(303.15 \mathrm{~K})$ to $90^{\circ} \mathrm{C}(363.15$ $\mathrm{K})$. Fig. 13 shows all results for this simulation where the heat exchange rate is influenced by this parameter. It is observed that the heat flux can increase when inlet temperature increases. With this parameter the heat exchange rate can take values from $25.2 \mathrm{~W} / \mathrm{m}$ to 305.5 $\mathrm{W} / \mathrm{m}$ with a difference of $280.3 \mathrm{~W} / \mathrm{m}$ that represents $1113 \%$ of the least thermal performance. The average inlet temperature influences the difference between inlet and outlet temperature and as consequence the heat exchange rate between the soil and the pile system.

\section{Final considerations}

The heat exchanger pile was studied to find out the optimal thermal performance. The previous analysis suggests an structure with a pile length $6 \mathrm{~m}$ depth and about $1.0 \mathrm{~m}$ of diameter (for this singular case). A higher heat exchange rate is archived when the pile system has 3 HDPE U-pipes (arranged every 120。) in the pile shaft with $2 \mathrm{~mm}$ thickness. Pipe thickness provides a better thermal result when the pipe wall is smaller due to the 
diminution of the thermal resistivity of the element. With a higher thermal conductivity for concrete and soil the thermal performance can reach every time a better thermal performance with the increment of their values. For this study concrete and soil with $3.0 \mathrm{~W} / \mathrm{mK}$ and 2.90 $\mathrm{W} / \mathrm{mK}$ respectively achieve this relationship.

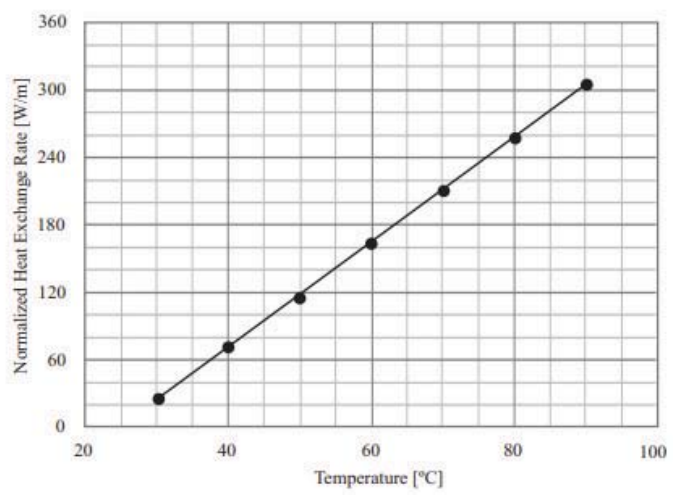

Fig. 13. Normalized heat exchange rate and variation of the inlet temperature.

Despite thermal regulations and limitation for the soil temperature, an average inlet temperature of $90{ }^{\circ} \mathrm{C}$ $(363.15 \mathrm{~K})$ gives as results a higher thermal performance (interesting for industries utilizations). Finally, the optimal configuration of the heat exchanger system is successfully modelled for a subtropical in the south region of Brazil east. The heat exchanger piles could be use for residential and industrial purposes long as exist an energy study for this application. For projects it is recommended to make a viability study for the optimal energy configuration of pile systems.

\section{Conclusions}

Simulations of a heat exchanger pile were successfully performed in COMSOL Multiphysics. The following conclusions can be drawn:

- The value of $73.5 \mathrm{~W} / \mathrm{m}$ reached in the thermal response test modelled is very higher (compared with traditional soils studied) due to the thermal important interaction of the soil components as iron oxides and minerals, very common in tropical soils.

- Pile geometry is an important matter to modify the thermal flux of the system. An increment of the pile length won't always increase the heat flux between soil and pile. Increment of diameter will help to obtain a higher value of heat exchange rate.

- Flow rate (passing for the 3 hydraulic regimes) produces a higher heat exchange when flow rate is increasing, except for the single U-pipe configuration which in turbulent regime the heat flux start to be constant. This performance can increase its growth rate in turbulent regime to the extend that flow rate is increasing too. Thermal flux between double and triple U-pipe configurations is not highly significant in this particular situation.
- A higher value of soil and concrete (type) thermal conductivity produce the increasing of the heat exchange rate in the pile system.

- Pipe thickness reduce the thermal performance when increase its value. This behaviour is related to the pipe 8 thermal resistivity.

- Thermal effects due the thermal conductivity of the surrounding soil and concrete were not very influential on the thermal performance of the heat exchanger pile while the variation of the concrete type can make an important contribution on the pile thermal response.

- The inlet temperature increment can improve the thermal pile performance when exists an increment of the inlet-outlet temperature difference (increment of the temperature gradient between fluid and soil).

\section{References}

1. A. Bidarmaghz, G.Narcilio, and I. Johnston, "Numerical modeling of ground heat exchangers with different ground loop configuration for direct geothermal applications." 18th ICSMGE, Paris, France, 2013.

2. Building Materials and Products - Hygrothermal Properties - Tabulated design values and procedures for determining declared and design thermal values, ISO, Geneva, Switzerland, 2007.

3. ANEEL. (2015) Tarifas da classe de consumo residencial de uma concessionária. [Online]. http://www.aneel.gov.br/area.cfm?idArea $=493$

4. L. Wadsö, J. Karlsson, and K. Tammo, "Thermal properties of concrete with various aggregates," $\mathrm{p}$. $25,2012$.

5. H. Brandl, "Energy piles for heating and cooling of buildings." Vienna, Austria: 7th International Conference \& Exhibition on Pilling and Deep Foundations, abr. 1998.

6. H. Brandl, "Energy piles and other thermo-active ground source sistems," Géotechnique, vol. 56, no. 2, pp. 81-122, 2006.

7. L. A. Neto, "Estudo experimental da resposta termica de fundaçoes por estacas trocadoras de calos em um solo nao saturado. Sao Carlos, Sao Paulo, Brasil: Universidade de Sao Paulo-EESC.” Master's thesis, 2015.

8. H. Castillo, "Validação do ensaio TRT para estudo paramétrico da troca de calor de uma estaca de energia em um solo tropical." 2016. xii, 169 f., il. Dissertação (Mestrado em Geotecnia)Universidade de Brasília, Brasília, 2016.

9. A. S. Peixot, "Estudo do ensaio SPT-T e sua applicaçao na pratica de engenharia de funfaçoes," Ph.D in Geotechnics, Campina State UniversityUNICAP, Campinas, Sao Paulo, Brazil, Jun. 2001.

10. F. Cecinato and F. A. Loveridge, "Influences on the thermal efficiency of energy piles," p. 13, 2015. 